\title{
KAJIAN KARAKTERISTIK PETANI KARET DALAM MENENTUKAN PILIHAN KELEMBAGAAN TATANIAGA DI PROVINSI ACEH
}

\author{
STUDY ON RUBBER FARMER' CHARACTERISTICS IN \\ DETERMINING THE TYPE OF MARKETING INSTITUTION IN ACEH \\ PROVINCE
}

\author{
Basri A. Bakar ${ }^{1}$ dan Emlan Fauzi ${ }^{2}$ \\ ${ }^{1) B a l a i}$ Pengkajian Teknologi Pertanian Aceh \\ ${ }^{2}$ Balai Pengkajian Teknologi Pertanian Bengkulu \\ Email: baskar_oline@yahoo.com
}

\begin{abstract}
Determining on rubber marketing institutional options is influenced by the characteristics of the institutional and socio-economic of farmers. This study aimed to examine the role of the characteristics of rubber farmers in the establishment of marketing institutional options. The research was conducted by survey method. The research has been taken in two districts of West Aceh and East Aceh. The numbers of respondents were 360 farmers. Data collection was taken by observation and structured interviews to a number of "key informants" and performed Focus Group Discussion (FGD) in strengthening and completing the information required. The results show the magnitude of institutional partnership opportunities for farmers to choose the traditional institutional was significantly influenced by the negative direction by the experience of farmers in rubber farming, farmers formal education, number of family member, and number of tapped rubber trees; and significantly and positively influenced by non-formal education and total family income. Total family income has an elastic response.
\end{abstract}

Keywords: Marketing Institutional, farmer Characteristics, rubber

\section{PENDAHULUAN}

Pembangunan pertanian merupakan bagian dari pembangunan nasional dan harus dilakukan secara terus menerus serta berdampak untuk meningkatkan kesejahteraan masyarakat. Peningkatan produksi pertanian tidak hanya dari segi kuantitas saja, tetapi juga kualitasnya sehingga dapat memenuhi bermacam kebutuhan masyarakat dan dapat meningkatkan devisa 
negara melalui ekspor hasil pertanian. Pembangunan sektor perkebunan merupakan bagian dari pembangunan pertanian yang dapat berperan dan mampu menggerakan sektor industri. Saat ini perkebunan merupakan salah satu subsistem di lingkungan pertanian yang memberikan sumbangan paling besar terhadap devisa negara dibandingkan dengan sub sektor lainnya.

Karet adalah salah satu komoditi perkebunan yang paling penting, baik dalam skala nasional maupun internasional. Di Provinsi Aceh, karet merupakan tanaman perkebunan terluas setelah tanaman kelapa sawit, dengan luas arealnya mencapai 109.104 ha $(21,86 \%)$ dari luas tanaman perkebunan yang ada dengan jumlah produksi sebesar 63,603 ton/ha atau $14,47 \%$ dari total produksi perkebunan utama Provinsi Aceh. Untuk mengetahui luas lahan dan produksi tanaman perkebunan rakyat utama Provinsi Aceh dapat dilihat pada tabel 1 berikut:

Tabel 1. Luas Lahan dan Produksi Perkebunan Rakyat Provinsi Aceh Tahun 2009

\begin{tabular}{clcccc}
\hline No & Komoditi & Luas Lahan & \% & Produksi (ton) & $\%$ \\
\hline 1 & Karet & 109.104 & 21,86 & 63.603 & 14,47 \\
2 & Sawit & 140.442 & 28,14 & 181.634 & 41,32 \\
3 & Coklat & 75.130 & 15,05 & 87.250 & 19,85 \\
4 & Kopi & 72.741 & 14,57 & 50.190 & 11,42 \\
5 & Kelapa & 101.751 & 20,38 & 56.875 & 12,94 \\
\hline
\end{tabular}

Sumber: BPS, 2010

Perkebunan rakyat masih dicirikan oleh produksi yang rendah, keadaan kebun yang kurang terawat, serta rendahnya pendapatan petani. Rendahnya produktivitas perkebunan karet rakyat juga disebabkan oleh terbatasnya modal yang dimiliki oleh petani, sehingga petani tidak mampu untuk menggunakan teknik-teknik budidaya yang sesuai dengan syarat-syarat teknis yang diperlukan.

Karet merupakan komoditas yang yang mempunyai prospek masa depan yang cukup baik, namun masih diperdagangkan secara tradisional. Mengingat usaha komoditas karet adalah usaha jangka panjang, maka peninjauan prospek komoditas tersebut merupakan hal yang sangat penting terutama dari segi pemasaran. Beberapa hal yang merupakan informasi menyangkut komoditi karet tersebut antara lain adalah mengenai perkembangan permintaan dan penawaran, perkembangan dari beberapa negara produsen dan konsumen karet alam termasuk keunggulan komparatif dan daya saing serta potensi pengembangannya. 
Secara empiris dapat ditemukan bahwa pada kelembagaan tataniaga formal petani pada awalnya memperoleh bagian harga yang lebih tinggi (Drajat, 1984; dalam Harris, 1998). Namun dalam perkembangan selanjutnya kelembagaan tersebut memperlihatkan keragaan yang kurang mengembirakan. Petani cenderung memilih jalur tataniaga tradisional melalui tengkulak, walaupun dalam prakteknya menerima bagian harga yang lebih kecil.

Pilihan terhadap kelembagaan ini sering dikaitkan dengan kuatnya ikatan emosional antara petani dengan pedagang yang terbentuk secara historis dengan menekankan pada unsur ketetanggaan atau kekerabatan. Namun kecenderungan demikian juga terjadi pada wilayah baru proyekproyek pengembangan karet rakyat. Menurut Kamal (2009), petani yang memasarkan bahan olah karet (bokar) ke pasar lelang hanya 43,33\% dan memasarkan ke pasar tradisional yaitu sebesar $57,67 \%$ dari jumlah petani.

Penentuan pilihan terhadap alternatif kelembagaan tataniaga bokar oleh petani karet dipengaruhi oleh karakteristik masing-masing kelembagaan alternatif dan karakteristik sosial ekonomi petani. Hobbs (1997), memperlihatkan bahwa selain karakteristik kelembagaan alternatif, karakteristik sosial ekonomi petani dan karakteristik usahatani memberikan pengaruh yang nyata terhadap penentuan pilihan kelembagaan tataniaga oleh petani.

Perkebunan karet rakyat memiliki keragaman dalam hal keadaan sosial ekonomi petani maupun karakteristik usaha kebunnya, misalnya pengalaman petani dalam usaha kebun karet, tingkat pendidikan formal petani, pendidikan non-formal, jumlah anggota keluarga, pendapatan keluarga dan aspek-aspek yang berhubungan dengan produksi kebun karetnya.

Secara teoritis memang belum ada yang menyatakan hubungan antara keadaan sosial ekonomi petani dan karakteristik usaha kebun dengan peluang pilihan kelembagaan, tetapi peubah-peubah ini diduga memiliki hubungan erat dengan pilihan kelembagaan tataniaga bokar oleh petani. Karakteristik individu petani serta usahataninya akan menjadi kendala bagi petani dalam usaha memperoleh manfaat yang mungkin dapat diperoleh dari setiap kelembagaan tataniaga alternatif yang tersedia. Tujuan dari penelitian ini adalah mempelajari peranan karakteristik petani karet dalam proses penentuan pilihan kelembagaan tataniaga.

\section{METODE PENELITIAN}

Penelitian ini dilakukan di lokasi perkebunan karet rakyat di Kabupaten Aceh Barat dan Aceh Timur yang dilaksanakan pada bulan Februari sampai dengan September 2012. Penelitian ini dilakukan dengan metode survei yang dilakukan di 18 desa dalam 6 kecamatan dan 2 kabupaten. Pemilihan desa 
lokasi dilakukan secara sengaja (purposive) dengan pertimbangan bahwa lokasi tersebut memiliki kelembagaan tataniaga bokar yang dikaji. Sampel dalam penelitian ini adalah petani karet yang dipilih secara acak dalam jumlah proporsional terhadap kerangka contoh, yang mewakili kelembagaan kemitraan dan kelembagaan tradisional, dengan jumlah responden sebanyak 360 petani.

Data yang dikumpulkan dalam pengkajian ini meliputi data primer dan data sekunder. Pengumpulan data primer dilakukan dengan cara melakukan observasi dan wawancara secara terstruktur dengan sejumlah "key informan" dan ditambah lagi dengan pelaksanaan Focus Group Discussion (FGD) untuk memperkuat serta melengkapi informasi yang dibutuhkan. Disamping itu, pengumpulan data sekunder dilakukan melalui kajian terhadap laporan pihak terkait guna memperkuat berbagai informasi yang diperoleh dari data primer.

Proses selanjutnya, data yang diperoleh dari hasil wawancara dengan sejumlah responden ditabulasi. Peubah karakteristik petani karet yang dipelajari dalam penelitian ini meliputi pengalaman petani dalam usaha kebun karet, tingkat pendidikan formal petani, pendidikan non-formal, besarnya keluarga, pendapatan keluarga dan aspek-aspek yang berhubungan dengan produksi kebun karetnya. Kajian karakteristik petani karet Aceh dalam menentukan pilihan kelembagaan tataniaga dianalisis dengan menggunakan model multinomial logit. Persamaannya sebagai berikut:

$$
\log P_{1} / P_{2}=a_{12}+\beta_{12} X_{1 i}+\gamma_{12} X_{2 i}+\theta_{12} X_{3 i}+\sigma_{12} X_{4 i}+8{ }_{12} X_{5 i}+{ }_{3}{ }_{12} X_{6 i}+\text { éi }
$$

dimana $\mathrm{X} 1$ adalah pengalaman dalam usahatani karet, $\mathrm{X} 2$ adalah pendidikan formal, $\mathrm{X} 3$ adalah pendidikan non-formal, $\mathrm{X} 4$ adalah jumlah anggota keluarga, $\mathrm{X} 5$ adalah total pendapatan keluarga, dan $\mathrm{X} 6$ adalah jumlah pohon karet yang dapat disadap.

Selanjutnya model tersebut di atas diestimasi dengan menggunakan metode OLS (Ordinary Least Square).

\section{HASIL DAN PEMBAHASAN}

\section{Struktur Kelembagaan Tataniaga Bokar}

Hasil penelitian menunjukkan bahwa secara umum ada dua kelembagaan tataniaga yang menjadi acuan bagi petani bokar untuk memasarankan hasil produksinya. Kedua lembaga ini dapat diaktegorikan sebagai lembaga tardisional dan kemtraan. Jika dilihat lebih detail, kedua lembaga ini memiliki karakteristik yang berbeda satu dengan lainnnya. Perbedaan ini dapat dilihat dalam penentuan atau pembentukan harga, bentuk hubungan antara agen pemasaran dan petani, dan sebagainya. Secara rinci, 
karakteristik kedua kelembagaan pemasaran ini dibahas pada sub-bab berikut ini.

\section{Kelembagaan Tradisional}

Kelembagaan tradisional dalam sistem pemasaran bokar merupakan kelembagaan yang telah lama berkembang di sentra-sentra produksi karet rakyat. Kelembagaan ini berkembang seiring dengan berkembangnya perkebunan karet rakyat. Dalam kelembagaan ini pedagang perantra memegang peranan yang sangat dominan. Pusat-pusat produksi karet rakyat yang lokasinya sampai ke pelosok pedesaan terpencil dihubungkan oleh pedagang perantara ini dengan pusat-pusat pengolahan yang umumnya berada di daerah perkotaan yang memiliki sarana dan prasarana ekspor. Antara pusat pengolahan dengan sentra produksi bokar yang terpencil terbentuk suatu hirarki pedagang dari pedagang pengumpul desa, pedagang tingkat kecamatan, pedagang tingkat kabupaten dan akhirnya sampai di pabrik pengolahan.

Dalam sistem pemasaran bokar, awalnya hanya dikenal kelembagaan ini, sehingga $100 \%$ bokar yang diproduksi petani dapat dikatakan ditransaksikan melalui kelembagaan ini. Kelembagaan tataniaga lain baru muncul setelah adanya proyek-proyek pengembangan karet rakyat. Hingga saat ini kelembagaan tradisional masih memiliki peran yang dominan dalam tataniaga bokar di Aceh.

Kelembagaan tradisional dalam tataniaga bokar telah banyak mengalami pergeseran, baik dalam hal hubungan antara pedagang dengan petani maupun praktek-praktek transaksinya. Pada lokasi yang relatif terpencil dengan sarana komunikasi dan transportasi yang masih terbatas, biasanya hanya ada satu atau dua pedagang bokar yang melakukan transaksi. Pedagang ini pada umumnya juga memiliki usaha lain seperti penyediaan bahan pokok sehingga secara umum memiliki kemampuan ekonomi yang lebih dibandingkan dengan masyarakat desa pada umumnya.

Dengan demikian hubungan antara pedagang dengan petani tidak terbatas pada transaksi bokar, tetapi juga menyangkut kebutuhan pokok dan pinjaman uang pada saat petani membutuhkan. Pada hakekatnya transaksi yang terjadi secara simultan ini adalah upaya memperkecil biaya transaksi dan sekaligus memperkecil risiko bagi kedua belah pihak yang melakukan transaksi.

Sifat produksi karet yang sangat dipengaruhi oleh keadaan iklim menyebabkan pada saat tertentu petani sama sekali tidak bisa menyadap sehingga tidak memperoleh pendapatan. Dalam keadaan demikian maka petani akan menggantungkan kebutuhan hidupnya kepada pedagang bokar, baik dalam bentuk kebutuhan pokok maupun pinjaman uang. Sebagai imbalan atas bantuan tersebut petani akan menjual seluruh bokar yang dihasilkan 
kepada pedagang sehingga terbentuk suatu ikatan secara informal yang saling menguntungkan antara kedua belah pihak dalam bentuk hubungan prinsipalagen.

Selalu ada anggapan bahwa harga yang ditetapkan pedagang sangat rendah, sehingga petani dirugikan. Namun pedagang sebagai agen juga menanggung risiko misalnya berupa kemungkinan tidak kembalinya pinjaman yang diberikan kepada petani walaupun persentasenya kecil. Di lain pihak petani sebagai prinsipal tampaknya tidak semata-mata memandang pada harga bokar yang akan diterima, tetapi pada kemudahan prosedur mendapatkan bantuan di saat memerlukan serta faktor keamanan keberlangsungan kehidupannya, sehingga pada kondisi demikian kedua belah pihak merasa memperoleh manfaat dari bentuk hubungan tersebut.

Pada perkembangan selanjutnya dimana prasarana dan sarana transportasi relatif baik, kelembagaan tradisional tetap memiliki peranan yang dominan. Pada kondisi demikian, persaingan antar pedagang bokar sebagai agen semakin meningkat yang ditunjukkan oleh semakin kecil indeks Herfindal sehingga mengarah pada kondisi yang lebih menguntungkan petani (Haris et al.1998). petani tidak lagi berhubungan dengan satu atau dua pedagang, tetapi dengan banyak pedagang, baik dari dalam dan luar desa yang bersangkutan. Bentuk prinsipal-agen antara petani dan pedagang tetap terjalin tetapi lebih bersifat temporal, karena petani bisa berpindah dari satu pedagang ke pedagang lain yang menurut anggapan petani lebih menguntungkan.

Periode transaksi bokar pada kelembagaan ini adalah satu minggu mengikuti dinamika ekonomi perdesaan yang telah mapan. Di wilayah Aceh, uroe pekan (pasar) desa yang dilakukan setiap minggu memiliki peran yang cukup penting dalam kegiatan ekonomi perdesaan terutama dalam transaksi kebutuhan pokok masyarakat. Transaksi bokar antara petani dan pedagang selalu dilakukan satu hari sebelum hari pasar (uroe pekan) dengan cara pembayaran tunai. Dengan demikian petani bisa membelanjakan hasil penjualan bokarnya guna memenuhi kebutuhan sehari-hari.

Kelembagaan tradisional dalam tata niaga bokar hanya memiliki dua pelaku utama yakni petani dan pedagang. Pedagang yang melakukan transaksi disuatu wilayah desa berasal dari desa yang telah memiliki cukup banyak informasi mengenai karakter petani dan bokar yang dihasilkan petani. Pedagang yang berasal dari luar desa biasanya tergolong pedagang besar yang telah memiliki hubungan dengan pabrik pengolahan dan telah memiliki sarana transportasi sendiri, sehingga mobilitasnya cukup tinggi. Penilaian pedagang terhadap mutu bokar dilakukan untuk setiap individu petani. Ini berarti tidak terjadi hubungan antara petani dalam proses transaksi bokar. Rendahnya mutu bokar yang dihasilkan satu petani tidak akan mempengaruhi proses transaksi bokar dari petani yang lain. Lain halnya pada sistem pemasaran kelompok yang penilaian mutu bokarnya didasarkan atas mutu bokar kelompok. 
Bentuk hubungan prinsipal-agen antara petani dengan pedagang cukup kuat. Walaupun terdapat cukup banyak pilihan pedagang, petani tidak secara mudah beralih dari satu pedagang ke pedagang yang lain, yang sering terjadi adalah proses negosiasi kembali antara petani dengan pedagang langganannya, jika terdapat ketidakcocok \an harga. Jika petani mendapat informasi harga bokar pada pedagang lain lebih tinggi, biasanya informasi ini disampaikan kepada pedagang sebagai agennya, kemudian terjadi negosiasi dan terbentuk harga kesepakatan baru.

Hak dan kewajiban petani sebagai prinsipal dan pedagang sebagai agen dalam kelembagaan tataniaga tradisional tidak secara eksplisit ditulis dalam suatu bentuk perjanjian, baik dalam proses transaksi bokar maupun dalam bentuk transaksi lainya. Aturan-aturan yang menjadi hak dan kewajiban petani dan pedagang merupakan pengetahuan yang secara luas sudah diketahui dan disepakati serta menjadi konsensus bersama walaupun ada sedikit variasi antara lokasi sentra produksi. Kelembagaan ini tidak memiliki standar khusus mutu bokar dalam transaksi. Penilaian mutu didasarkan atas pengamatan visual saja. Pedagang umumnya telah memiliki standar mutu sebagai patokan untuk menentukan harga bokar.

Transaksi lain selain bokar antara petani dengan pedagang adalah dalam bentuk pinjaman uang. Pinjaman ini tidak dikenakan bunga dan diberikan kepada petani yang memerlukan dengan prosedur yang sangat mudah, baik dalam jumlah, cicilan pengembalian pinjaman maupun ketersediaanya saat diperlukan, walaupun diperlukan ditengah malam. Bila petani sudah memiliki pinjaman uang, secara moral petani akan menjual bokarnya kepada pedagang yang memberi pinjaman uang tersebut. Harga bokar ditetapkan oleh pedagang dan apabila ada sedikit perbedaan harga dengan pedagang lainya, secara umum petani menerimanya dan tidak terdapat kecenderungan untuk pindah ke pedagang lainya pada transaksi berikutnya. Batas maksimal perbedaan harga yang masih dapat diterima petani adalah berkisar Rp. 10-30,-/ kg bokar.

Adanya persaingan antar pedagang untuk mendapatkan bokar dari petani mendorong pedagang meningkatkan pelayanan pembelian kepada petani. Sebagian besar petani $(75 \%)$ di lokasi penelitian kecuali desa Bireuen Bayeun, melakukan transaksi bokar dengan pedagang di tempat tinggal petani, bahkan di Desa Alue Batee beberapa pedagang melakukan transaksi bokar di kebun petani. Pedagang biasanya menggunakan alat angkut yang ada dan menimbang bokar dari rumah ke rumah. Implikasinya adalah petani memperoleh kemudahan dan terbebas dari biaya angkutan bokar dari tempat penyimpanan ketempat penjualan. Sebaliknya bagi pedagang, pengumpulan bokar menjadi beban yang menjadi komponen biaya pemasaran.

Dalam kelembagaan tataniaga tradisional, yang memiliki informasi harga tetap adalah pedagang, karena merekalah yang memiliki akses ke informasi harga yang pada umumnya bersumber dari pabrik pengolahan sebagai 
eksportir. Namun karena cukup banyak pedagang maka cukup banyak pula informasi harga yang diperoleh petani. Petani dapat menegosiasikan harga transaksi bokar jika merasa tidak cocok, dan menentukan besarnya potongan basi. Hak dan kewajiban yang mengikat petani dan pedagang dalam suatu transaksi seluruhnya dibuat atas dasar kesepakatan secara informal. Oleh karena itu, norma-norma dan kearifan lokal sangat berperan sebagai pengendali pelaksanaan penegakan hak dan kewajiban tersebut.

\section{Kelembagaan Mitra}

Transaksi bokar dilakukan empat kali dalam satu bulan. Transaksi berlangsung setiap hari Rabu untuk Kabupaten Aceh Timur sedangkan untuk Kabupaten Aceh Barat berlaku setiap hari Senin dan Selasa. Transaksi terjadi di rumah ketua kelompok, sehingga setiap anggota kelompok harus membawa bokarnya ke rumah ketua kelompok. Setelah semua bokar dikumpulkan kemudian pengurus membawanya ke pabrik pengolah yang ada di Medan Sumatera Utara. Transaksi harga bokar ditetapkan oleh perusahaan, sedangkan kedudukan petani hanya sebagai penjual penerima harga (price taker). Pihak yang menjadi pelaku utama dalam proses transaksi adalah petani dengan kelompok taninya. Pemasaran secara terorganisir seperti halnya melalui kelembagaan kemitraan masyarakat berlaku pembakuan mutu. Hal ini penting mengingat penilaian mutu bokar tidak dilakukan per indidvidu petani, tetapi nilai dalam kelompok secara keseluruhan menjadi satu jenis mutu dan menjadi satu jenis harga jual.

\section{Penentuan Pilihan Kelembagaan Tataniaga Karet oleh Petani}

Hasil analisis pilihan kelembagaan tataniaga bokar oleh petani disajikan pada Tabel 2, selanjutnya pembahasan menekankan pada perbandingan peluang pilihan kelembagaan kemitraan (P1) terhadap kelembagaan tradisional (P2). Kelembagaan kemitraan merupakan bentuk kelembagaan formal yang terorganisir dengan karekteristik yang berbeda. Sementara kelembagaan tradisional merupakan kelembagaan yang telah mapan keberadaannya.

Hasil analisis menunjukkan bahwa peluang kelembagaan kemitraan terhadap kelembagaan tradisional (P1/P2) yang dipilih petani dipengaruhi secara nyata oleh semua peubah karakteristik petani yang dimasukkan dalam analisis yakni pengalaman dalam usahatani karet, pendidikan formal, pendidikan non formal, jumlah anggota keluarga, total pendapatan keluarga dan jumlah pohon karet yang dapat disadap.

Meningkatnya pengalaman petani dalam usahatani karet cenderung memperkecil peluang petani memilih kelembagaan kemitraan. Peluang kelembagaan kemitraan dipengaruhi secara negatif oleh peubah pengalaman dalam usahatani karet. Hal ini dapat dipahami bahwa petani yang lebih lama 
memiliki pengalaman dalam usahatani cenderung memiliki keterkaiatan yang lebih erat dengan pedagang bokar dibandingkan dengan petani yang memiliki pengalaman relatif baru dalam usahatani karet.

Tabel 2. Dugaan Koefisien Fungsi Multinomial Logit Pilihan Kelembagaan Tataniaga bokar

\begin{tabular}{clc}
\hline No & \multicolumn{1}{c}{ Peubah Bebas } & $\begin{array}{c}\text { Peubah Perbandingan } \\
\text { Peluang Log (P1/P2) }\end{array}$ \\
\hline 1 & Konstanta & 1,526 \\
2 & Pengalaman dalam usahatani karet & $-0,024^{* *}$ \\
3 & Pendidikan formal & $-0,418^{* *}$ \\
4 & Pendidikan non-formal & 0,044 \\
5 & Jumlah anggota keluarga & $-0,322^{* *}$ \\
6 & Total pendapatan keluarga & $0,236^{* * *}$ \\
7 & Jumlah pohon karet yang dapat disadap & $-0,002^{* * *}$ \\
\hline
\end{tabular}

Ket : *** : Nilai t nyata pada $\alpha=0,01$

** : Nilai t nyata pada $\alpha=0,05$

* : : Nilai t nyata pada $\alpha=0,10$

Pedagang bokar dengan petani di pedesaan sentra karet rakyat biasanya memiliki ikatan secara turun temurun. Petani yang telah lama menjadi langganan orang tua mereka biasanya secara otomatis menjadi langganan pedagang penerusnya. Keterikatan demikian terbentuk secara kuat karena seperti dijelaskan sebelumnya bahwa hubungan pedagang dengan petani biasanya tidak terbatas pada transaksi bokar tetapi juga pada jenis-jenis pinjaman seperti pinjaman uang.

Bentuk hubungan ini berkembang menjadi keterikatan secara moral dan bagi petani perlakuan pedagang seperti ini sangat dirasakan manfaatnya karena bisa mendapatkan bantuan yang diperlukan pada saat membutuhkan. Lain halnya dengan petani yang relatif baru dalam usahatni karet. Mereka lebih cenderung memilih kelembagaan kemitraan dari pada pedagang kelembagaan tradisional.

Besarnya peluang pilihan kelembagaan kemitraan dibanding kelembagaan tradisional juga dipengaruhi oleh peubah jumlah anggota keluarga. Semakin besar jumlah anggota keluarga maka peluang petani memilih kelembagaan kemitraan semakin kecil. Peubah ini berkaitan dengan tingkat pengeluaran keluarga serta ketidaktentuan pengeluaran. Keadaan demikian mendorong petani berhubungan dengan pedagang bokar. Ini terjadi terutama pada keluarga besar yang anak-anaknya banyak yang sedang dalam usia sekolah. 
Dalam kondisi demikian terjadi kebutuhan yang sifatnya mendadak dan belum dapat diakomodasi sepenuhnya oleh kelembagaan kemitraan. Keterbatasan pelayanan yang dapat diberikan oleh kelompok tani kepada petani anggota ini mendorong petani lebih memilih pedagang yang memiliki fleksibilitas tinggi dalam prosedur transaksi.

Besarnya peluang kelembagaan kemitraan dengan kelembaganan tradisional dipengaruhi secara negatif dan nyata oleh tingkat pendidikan formal. Ini menunjukkan bahwa petani yang memiliki pendidikan formal lebih tinggi, cenderung lebih memilih kelembagaan tradisional dibandingkan dengan kelembagaan kemitraan. Hal ini disebabkan oleh meningkatnya pengetahuan petani dalam proses transaksi bokar, sehingga kemampuan negosiasi dengan pedagang akan semakin kuat dibanding petani yang memiliki pendidikan formal yang lebih rendah.

Pendidikan non formal petani dalam bidang usahatani karet yang diperoleh melalui berbagai kursus ternyata berpengaruh secara nyata terhadap besarnya peluang kelembagaan kemitraan dibandingkan dengan kelembagaan tradisional. Petani yang telah mengikuti lebih banyak kursus-kursus usahatani karet cenderung memilih kelembagaan kemitraan dibandingkan dengan kelembagaan tradisional. Hal ini disebabkan hubungan tingkat kepedulian petani terhadap peningkatan mutu bokar. Peningkatan mutu bokar pada kelembagaan tradisional sulit untuk dilakukan baik petani maupun pedagang tidak mendapatkan cukup banyak insentif untuk melakukannya.

Perbandingan peluang kelembagaan kemitraan dengan tradisional juga di pengaruhi oleh besarnya jumlah pendapatan keluarga. Semakin tinggi pendapatan keluarga semakin besar peluang petani memilih kelembagaan kemitraan. dengan semakin besarnya tingkat pendapatan petani, peluang petani untuk melakukan transaksi dengan pedagang bokar menurun, karena kebutuhan keluarga relatif lebih dapat dipenuhi.

Selanjutnya peluang kelembagaan kemitraan dibandingkan dengan kelembagaan tradisional dipengaruhi secara negatif oleh jumlah pohon karet yang disadap oleh petani. Hal ini dikarenakan petani pemilik yang memiliki jumlah pohon karet yag lebih banyak cenderung menerapkan sistem bagi hasil dalam mengelola usahatani karetnya.

Elastisitas peluang pilihan kelembagaan kemitraan memiliki elastisitas yang negatif terhadap peubah pengalaman petani dalam berusahatani karet, pendidikan formal petani, jumlah anggota keluarga dan jumlah pohon karet yang disadap. Sedangkan terhadap peubah pendidikan non formal dan jumlah pendapatan keluarga memiliki elastisitas yang bersifat positif. Elastisitas respon dari peubah total pendapatan keluarga bersifat elastis dengan nilai elastisitas sebesar 1,3. Ini berarti jika terjadi kenaikan 1 unit jumlah pendapatan keluarga maka akan meningkatkan peluang petani memilih kelembagaan 
kemitraan sebesar 1,3\%. Sementara peubah yang lain tidak bersifat elatis karena nilainya di bawah 1 .

\section{SIMPULAN DAN SARAN}

Besarnya peluang petani memilih kelembagaan kemitraan terhadap kelembagaan tradisonal dipengaruhi secara nyata dengan arah negatif oleh pengalaman petani dalam usahatani karet, pendidikan formal petani, jumlah anggota keluarga petani dan jumlah pohon karet yang disadap serta dipengaruhi secara nyata dan positif oleh pendidikan non formal dan total pendapatan keluarga. Peubah total pendapatan keluarga memiliki elastisitas respon yang bersifat elastis. Pentingnya kelembagaan pemasaran tradisional bagi sebagian petani ini tampaknya tidak dapat diambil alih oleh kelembagaan kemitraan. Oleh sebab itu, pentingnya informasi harga bagi petani untuk dapat memperkuat posisi tawar mereka harus menjadi kebijakan utama dalam meningkatkan pendapatan dan kesejahteraan petani bokar dan keluarganya.

\section{DAFTAR PUSTAKA}

Angkasa Wisman Indra, Bambang Risdianto, Kasman. 2003. Pengkajian Mekanisme Difusi Teknologi Tepat Guna Pertanian. Prosiding Seminar Teknologi untuk Negeri 2003, Vol. V, Hal. 140 - 155 /HUMASBPPT/ANY.

Arifin, A. 1994. Strategi Komunikasi. Sebuah Pengantar Ringkas. Armico. Bandung.

Badan Pusat Statistik Provinsi Nanggroe Aceh Darussalam. 2010. Aceh dalam Angka 2009. Kerjasama Badan Pusat Statistik NAD dan Bapeda NAD, 197 - 207.

Balai Pengkajian Teknologi Pertanian NAD, 2009. Pengelolaan Terpadu Padi Sawah untuk Meningkatkan Produktivitas Padi di Provinsi Aceh. Makalah disampaikan pada Seminar Sehari Fakultas Pertanian Universitas Syiah Kuala.

Kasryno F, dan N. Syafa'at. 2000. Strategi Pembangunan Pertanian yang Berorientasi Pemerataan di Tingkat Petani, Sektor dan Wilayah. Prosiding Persfektif Pembangunan Pertanian dan Pedesaan dalam Era Otonomi Daerah. Puslit Sosial Ekonomi Pertanian, Badan Litbang Pertanian, Departemen Pertanian, Jakarta. $397 \mathrm{hlm}$.

Mulyani Eko Sri, Retno Sri Hartati Mulyandari, dan Penny I. Iskak. 2006. Pengkajian Penyampaian Inovasi Pertanian Melalui Pameran Di Kalimantan Barat. Jurnal Perpustakaan Pertanian. 15, (2) : 23-31. 
Nazari, M. 1996. Analisis Efisiensi Pemasaran Karet di Kabupaten Musi Rawas Sumatera Selatan. Tesis S2 Universitas Brawijaya (unpublished). Malang.

Nazir, M. 1988. Metode Penelitian. Ghalia Indonesia. Jakarta.

Pitaloka Dyah, Ani S.S. dan Jeffry. 2005. Penyempurnaan Tata Laksana Penyiapan Dan Penerapan Paket Teknologi Pertanian (Revisi Keputusan Menteri Pertanian No. 804/1995).

Simatupang, P. 2004. Prima Tani sebagai Langkah Awal Pengembangan Sistem dan Usaha Agribisnis Industrial. Analisis Kebijakan Pertanian. 2(3): 209-225.

Yuprin, A.D. 2009. Analisis Pemasaran Karet Di Kabupaten Kapuas. Jurnal. WACANA Vol. 12 No. 3. Bogor. 